Prepared in cooperation with the National Fish and Wildlife Foundation

\title{
Shoreface and Holocene Sediment Thickness Offshore of Rockaway Peninsula, New York
}

Open-File Report 2021-1100 



\section{Shoreface and Holocene Sediment Thickness Offshore of Rockaway Peninsula, New York}

By Emily A. Wei, Jennifer L. Miselis, and Arnell S. Forde

Prepared in cooperation with the National Fish and Wildlife Foundation

Open-File Report 2021-1100 


\section{U.S. Geological Survey, Reston, Virginia: 2021}

For more information on the USGS - the Federal source for science about the Earth, its natural and living resources, natural hazards, and the environment—visit https://www.usgs.gov or call 1-888-ASK-USGS.

For an overview of USGS information products, including maps, imagery, and publications, visit https://store.usgs.gov/.

Any use of trade, firm, or product names is for descriptive purposes only and does not imply endorsement by the U.S. Government.

Although this information product, for the most part, is in the public domain, it also may contain copyrighted materials as noted in the text. Permission to reproduce copyrighted items must be secured from the copyright owner.

Suggested citation:

Wei, E.A., Miselis, J.L., and Forde, A.S., 2021, Shoreface and Holocene sediment thickness offshore of Rockaway Peninsula, New York: U.S. Geological Survey Open-File Report 2021-1100, 14 p., https://doi.org/10.3133/ofr20211100.

Associated data for this publication:

Forde, A.S., Wei, E.A., DeWitt, N.T., and Miselis, J.L., 2021, Archive of chirp subbottom profile data collected in 2019 from Rockaway Peninsula, New York: U.S. Geological Survey data release, https://doi.org/10.5066/P9Z080KJ.

Stalk, C.A., DeWitt, N.T., Wei, E.A., Farmer, A.S., Miselis, J.L., and Fredericks, J.J., 2020, Coastal bathymetry and backscatter data collected in September and October 2019 from Rockaway Peninsula, New York: U.S. Geological Survey data release, https://doi.org/10.5066/P9WNJSFN.

ISSN 2331-1258 (online) 


\section{Contents}

Abstract

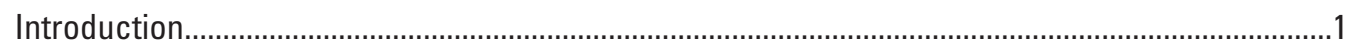

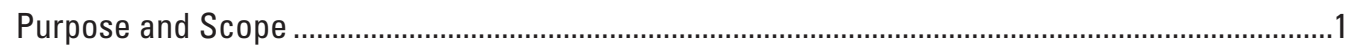

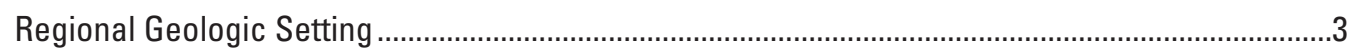

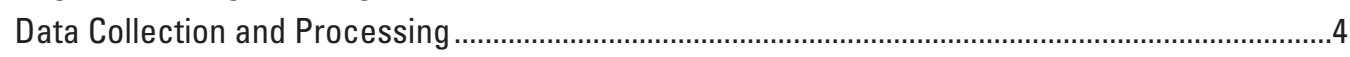

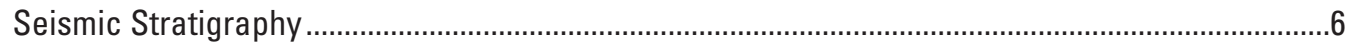

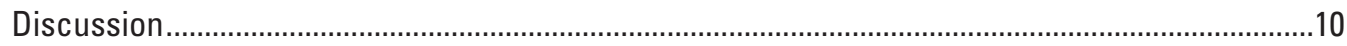

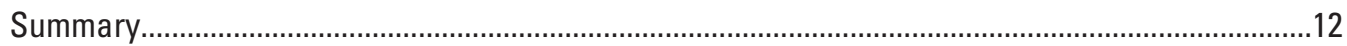

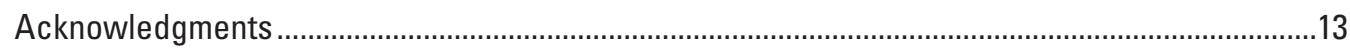

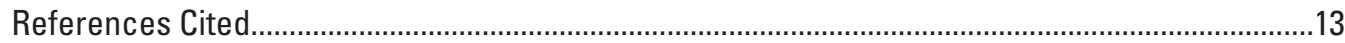

\section{Figures}

1. Map showing Rockaway Peninsula study area in southwest Long Island, New York .....2

2. Maps showing multibeam and single-beam bathymetry and multibeam

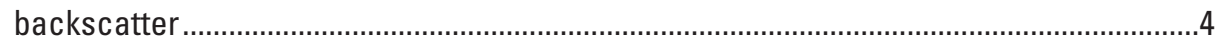

3. Graphs showing uninterpreted and interpreted dip profiles showing configurations of shoreface sediment, Holocene sediment above the regional unconformity, and underlying channels.

4. Graphs showing uninterpreted and interpreted profile of strike line 65 show the westward dip of the regional unconformity, westward thickening of Holocene sediment, and thickening Holocene sediment in the east because of the ebb-tide delta.

5. Maps showing shoreface and Holocene sediment thickness and depth of the regional unconformity

6. Graphs showing Holocene and shoreface sediment volume and ratio for zones I, II, III, and IV

\section{Tables}

1. Volumes of Holocene and shoreface sediment deposits subdivided by region

2. Volumes of Holocene and shoreface units at each shore-perpendicular chirp line transect.

\section{Conversion Factors}

U.S. customary units to International System of Units

\begin{tabular}{lccc}
\hline & Multiply & By & To obtain \\
\hline & Length & & \\
\hline foot $(\mathrm{ft})$ & 0.3048 & meter $(\mathrm{m})$ & \\
\hline
\end{tabular}


International System of Units to U.S. customary units

\begin{tabular}{|c|c|c|}
\hline Multiply & By & To obtain \\
\hline \multicolumn{3}{|c|}{ Length } \\
\hline millimeter (mm) & 0.03937 & inch (in.) \\
\hline meter $(\mathrm{m})$ & 3.281 & foot $(\mathrm{ft})$ \\
\hline meter (m) & 1.094 & yard (yd) \\
\hline kilometer (km) & 0.6214 & mile (mi) \\
\hline kilometer (km) & 0.5400 & mile, nautical (nmi) \\
\hline \multicolumn{3}{|c|}{ Area } \\
\hline square meter $\left(\mathrm{m}^{2}\right)$ & 0.0002471 & acre \\
\hline square meter $\left(\mathrm{m}^{2}\right)$ & 10.76 & square foot $\left(\mathrm{ft}^{2}\right)$ \\
\hline square kilometer $\left(\mathrm{km}^{2}\right)$ & 247.1 & acre \\
\hline square kilometer $\left(\mathrm{km}^{2}\right)$ & 0.3861 & square mile $\left(\mathrm{mi}^{2}\right)$ \\
\hline \multicolumn{3}{|c|}{ Volume } \\
\hline cubic meter $\left(\mathrm{m}^{3}\right)$ & 35.31 & cubic foot $\left(\mathrm{ft}^{3}\right)$ \\
\hline cubic meter $\left(\mathrm{m}^{3}\right)$ & 1.308 & cubic yard $\left(\mathrm{yd}^{3}\right)$ \\
\hline cubic meter $\left(\mathrm{m}^{3}\right)$ & 0.0008107 & acre-foot (acre-ft) \\
\hline \multicolumn{3}{|c|}{ Flow rate } \\
\hline meter per second $(\mathrm{m} / \mathrm{s})$ & 3.281 & foot per second $(\mathrm{ft} / \mathrm{s})$ \\
\hline
\end{tabular}

\section{Datum}

Vertical coordinate information is referenced to the North American Vertical Datum of 1988 (NAVD 88).

Horizontal coordinate information is referenced to the World Geodetic System of 1984 (WGS 84). Depth, as used in this report, refers to distance below the vertical datum.

\section{Supplemental Information}

For chirp data, frequencies are given in kilohertz $(\mathrm{kHz})$, pulse length is given in milliseconds, and ping rate is given in hertz.

\section{Abbreviations}

DEM digital elevation model

GPS global positioning system

USACE U.S. Army Corps of Engineers

USGS U.S. Geological Survey 


\title{
Shoreface and Holocene Sediment Thickness Offshore of Rockaway Peninsula, New York
}

\author{
By Emily A. Wei, Jennifer L. Miselis, and Arnell S. Forde
}

\section{Abstract}

During September and October 2019, the U.S. Geological Survey mapped the shoreface and inner continental shelf offshore of the Rockaway Peninsula in New York using high-resolution chirp seismic reflection and single-beam bathymetry geophysical techniques. The results from this study are important for assessing the Quaternary evolution of the Rockaway Peninsula and determining coastal sediment availability, which is crucial for establishing sediment budgets, understanding sediment dispersal, and managing coastlines. This report presents preliminary interpretations of seismic profiles and maps of shoreface and Holocene sediment thickness from the shoreline to about 2 kilometers offshore. The results indicate that shoreface and Holocene sediment thickness demonstrates zonal variability because of underlying geology and sediment availability. Based on geomorphic features and underlying stratigraphy, the study area is separated into west, west-central, east-central, and east zones. Holocene sediment, which includes the shoreface and seafloor features with positive morphology (for example, nearshore bars, ebb-tide deltas, and sorted bedforms), thickens to the west and may be related to accommodation and westward dip of the regional unconformity. Shoreface units, which are thought to represent the active volume of littoral sediment, are thickest in the west-central peninsula where the geologic base of the shoreface is deeper. Shoreface units with moderate thickness are in the western and eastern peninsula where there are positive morphological features (for example, deposits accumulating updrift from the jetty, ebb-tide deltas, and so on). The thinnest shorefaces are in the east-central Rockaway Peninsula because of less accommodation caused by the shoaling regional unconformity.

\section{Introduction}

Quantifying coastal sediment availability is relevant for coastal management because the volume of mobile, nearshore sediment has been linked to patterns of shoreline erosion on coastal margins (Miselis and McNinch, 2006); furthermore, the availability of shelf sediment may affect long-term coastal behavior (Schwab and others, 2014). The study site, the Rockaway Peninsula in New York, has historically demonstrated along-margin variability in short- $\left(10^{0}\right.$ to $10^{1}$ years $)$ and long-term ( $10^{2}$ to $10^{3}$ years) erosion, with short-term erosion in the east-central peninsula and accretion in the western Rockaway Peninsula (Hapke and others, 2010; U.S. Army Corps of Engineers [USACE], 2019). To mitigate erosion of the coastline and damage to coastal infrastructure, the USACE and beach communities periodically nourish the beach (USACE, 2019). Nevertheless, this region is vulnerable to winter storms (nor'easters) and occasional hurricanes, such as Hurricane Sandy in 2012, which caused substantial damage to or destroyed 1,000 coastal structures (USACE, 2019).

This investigation aims to quantify the volume of sediment in the "active shoreface" to improve understanding of spatial variability in barrier storm response. The active shoreface is the region over which morphological change is rapid enough to adjust to the annual range in wave conditions (Stive and de Vriend, 1995). Despite advances in understanding the linkages between shoreface slope and barrier response (Cowell and Kinsela, 2018), much is still not known about shoreface geology. Shorefaces are in shallow water; therefore, they can be difficult to map with seismic reflection equipment because breaking waves and shallow water restrict boat access and pose substantial hazards to towed seismic equipment. Nevertheless, this information would support several objectives, including an evaluation of the response of the peninsula to post-Hurricane Sandy coastal restoration projects, quantification of barrier peninsula sediment budgets, and prediction of the resilience of the barrier peninsula to storms and sea-level rise.

\section{Purpose and Scope}

In support of the previously stated objectives and in cooperation with the National Fish and Wildlife Foundation, the U.S. Geological Survey (USGS) completed a geophysical survey to understand how the geologic framework affects sediment availability offshore of the Rockaway Peninsula in New York (fig. 1; Stalk and others, 2020; Forde and others, 2021). Using a modified beach-launched towed sled, chirp seismic data were collected in water as shallow as 2 meters (m), allowing researchers to image more of the upper and lower shoreface than typical seismic studies. This report interprets these shallow-water chirp data and presents maps of shoreface and Holocene sediment thickness. Results from this report add to our knowledge of shoreface and inner shelf systems, especially those that are subject to anthropogenic modifications. 


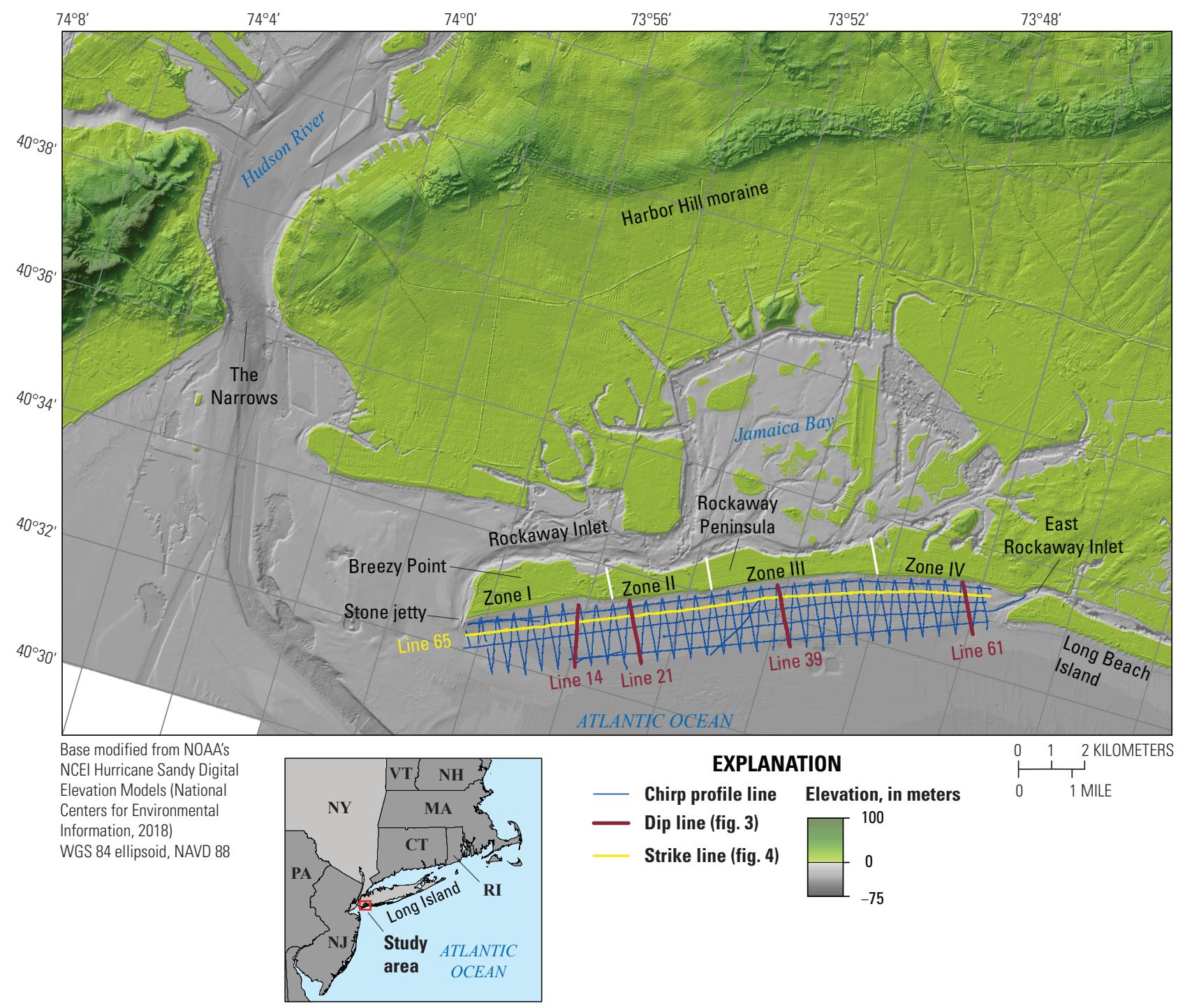

Figure 1. Rockaway Peninsula study area in southwest Long Island, New York. The geophysical survey spans the area from the nearshore to about 2 kilometers offshore of the Rockaway Peninsula. Chirp profile lines acquired over the survey (blue lines), dip lines (red; fig. 3A-D), and a strike line (yellow; fig. 4) also are shown. The extents of geomorphic zones are indicated by the white lines on the barrier peninsula. [WGS 84, World Geodetic System of 1984; NAVD 88, North American Vertical Datum of 1988; NOAA, National Oceanic and Atmospheric Administration; NCEI, National Centers for Environmental Information] 


\section{Regional Geologic Setting}

The study area is in southwest Long Island, New York, which was formed by the younger Harbor Hill and older Ronkonkoma terminal moraines during the last glacial advance (Taney, 1961). To the north of the Rockaway Peninsula lies the northeast-trending Harbor Hill moraine (fig. 1; Stone and Borns, 1986), and to the south, the peninsula is flanked by glaciofluvial outwash (Taney, 1961). Erosion and reworking of glacially derived sediment have contributed to much of the marine sediment offshore of Rockaway (Williams and Duane, 1974).

Rockaway Peninsula is a long linear barrier spit, formed in a microtidal environment and dominated by storm and wave processes, such as overwash and breaching (Hapke and others, 2010). Tidal currents at the Rockaway Peninsula are generally weak; however, they increase in velocity at Rockaway Inlet and East Rockaway Inlet (USACE, 2019). Winds averaged from 1950 to 2019 are predominantly from the south and range from 4.5 to 6.3 meters per second $(\mathrm{m} / \mathrm{s})$, and stronger storm-related winds are predominantly from the west and northwest with peak gusts from 21 to $32 \mathrm{~m} / \mathrm{s}$, as measured at John F. Kennedy Airport (USACE, 2019). This wind forcing affects wave approach to the Rockaway Peninsula, which is primarily from the south and southeast (USACE, 2019). From a 32-year record of wave climate, significant wave heights are about $0.96 \mathrm{~m}$ with an average dominant period of 8.20 seconds (Brutsché and others, 2016).

Although other barrier islands in the New York Bight, such as Fire Island, were formed about 8,000 years ago (Rampino and Sanders, 1981), Rockaway Peninsula is thought to be much younger, having formed within only the past 400 years by westward-moving longshore sediment transport (Taney, 1961; Sanderson, 2016). Over the past 125 years,
Rockaway Peninsula has extended to the southwest by more than 6.4 kilometers (km; USACE, 2016). The peninsula's progradation rate was rapid until 1902, at which point, progradation rates decreased by 50 percent from 1902 to 1927 (Sanderson, 2016; USACE, 2016, 2019).

Rockaway Peninsula also has a long history of human alterations. Anthropogenic modification and the construction of jetties and groins beginning in 1914 contributed to stabilization of the Rockaway Peninsula shoreline (USACE, 2016). On the western end of the peninsula, a 2,560-m-long stone jetty was constructed in 1933 to stabilize the eastern side of Rockaway Inlet, and it is regularly dredged to maintain a depth of -20 feet (fig. 1; USACE, 2019). After jetty construction, the western peninsula began to rapidly prograde seaward during the late 19th century, and progradation is continuing at present (2021; USACE, 2016). This progradation provided land for the establishment of the Breezy Point community on the western end of the peninsula (fig. 1). Additionally, the East Rockaway Inlet is stabilized by a jetty on its eastern side that was constructed in 1935 and is regularly dredged to maintain a depth of -12 feet (USACE, 2019). Initial beach nourishment efforts that supplied sand to beaches along the peninsula were recorded as early as 1926, and subsequent beach renourishment projects between 1936 and 1965 occurred in response to large storm events (USACE, 2019). The most extensive shoreline modification efforts began as part of the 1965 Flood Control Act in response to a severe storm in 1962 (USACE, 2019). Since 1975, beaches at Rockaway Peninsula have been renourished every 1-4 years with an average nourishment volume of $5.2 \times 10^{6}$ cubic meters (USACE, 2019). The sediment used for sediment renourishment is typically dredged from the inner shelf and dredge pits can be identified in bathymetric maps (fig. $2 A$ ). 


\section{A. Multibeam and single-beam bathymetry}

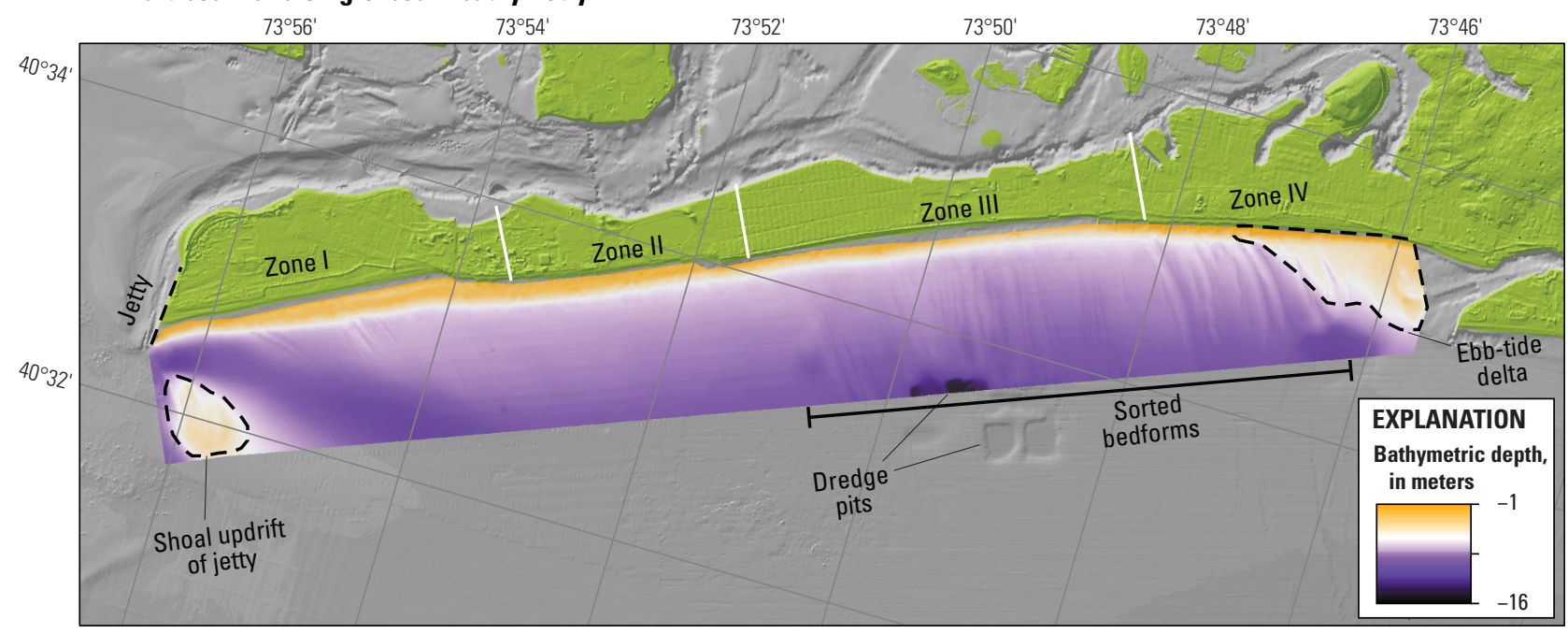

\section{B. Multibeam backscatter}

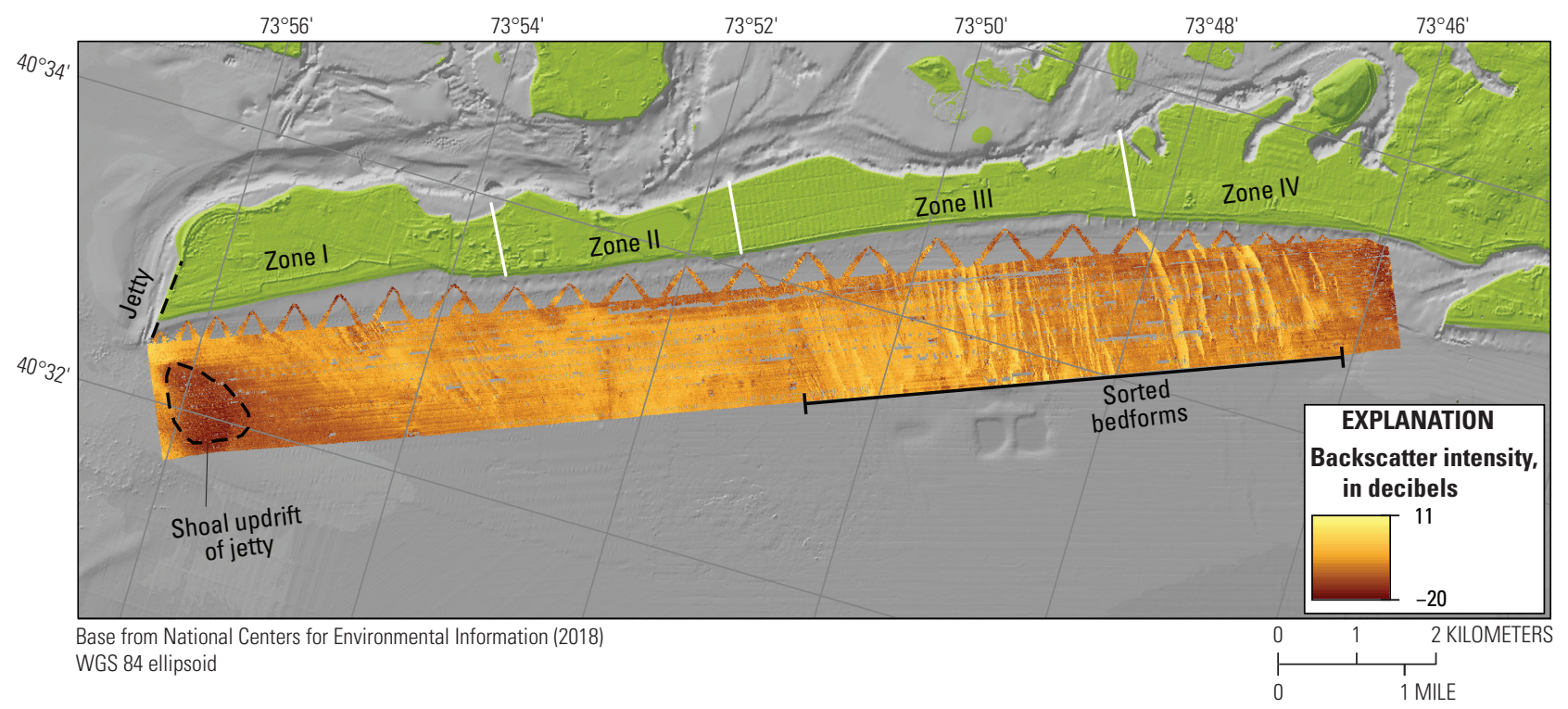

Figure 2. Multibeam and single-beam bathymetry and multibeam backscatter. $A$, multibeam bathymetry, in meters below the North American Vertical Datum of 1988; Selected features with positive morphology are annotated. $B$, multibeam backscatter. High intensity (bright colors) generally corresponds to harder seafloor substrate or increased roughness, whereas low intensity (dark colors) generally corresponds to softer seafloor substrate. [WGS 84, World Geodetic System of 1984]

\section{Data Collection and Processing}

Between September 24 and October 14, 2019, 201 kilometers of chirp seismic data were acquired as part of USGS field activity 2019-333-FA (https://cmgds.marine.usgs.gov/ fan_info.php?fan=2019-333-FA) in the nearshore region of the Rockaway Peninsula in water depths of 2-16 $\mathrm{m}$ and extending about $2 \mathrm{~km}$ offshore to the inner shelf (fig. 1) aboard the USGS research vessel Sallenger (Forde and others, 2021). An EdgeTech SB-512i subbottom profiler and Ashtech Proflex 800 global positioning system (GPS) receiver were strapped to a purpose-built, towed sled platform modified by USGS scientists to collect chirp seismic data in shallow-water environments. The seismic sled is buoyed by two inflatable pontoon floats that allow the chirp profiler to rest just below the water's surface during seismic acquisition and enable launching and recovery from the shore. Additionally, the seismic sled was configured to ensure the quality of data collected in shallow-water depths and reduce signal-multiple artifacts by allowing for minimal offset between the water surface and the chirp receiver. Chirp data were acquired at frequencies ranging from 0.7 to 12 kilohertz $(\mathrm{kHz})$, a pulse length of 20 milliseconds, and a ping rate of 5 hertz. Data were recorded in EdgeTech proprietary JSF and industry standard SEG-Y formats. More information on chirp acquisition is available in a USGS data release (Forde and 
others, 2021). During chirp acquisition, information about the position of each seismic shot was collected by a sled-mounted Ashtech Proflex 800 GPS receiver and was written to the seismic trace headers. Differential positioning was obtained through postprocessing the base station data (on the USGS established benchmark RIIS) to the Proflex on the sled. More information on positional accuracy and navigation details specific to GPS and bathymetry data is available in a USGS data release (Stalk and others, 2020).

Also mounted on the seismic sled was an Odom Echotrac CV100 single-beam echo sounder that acquired bathymetry. Single-beam data were merged with navigation data and corrected for sound velocity and tides, as described by Stalk and others (2020). Data were then processed and cleaned within CARIS HIPS and SIPS data processing software. Further details of single-beam bathymetry processing are available in Stalk and others (2020). Single-beam bathymetry soundings collected onboard the chirp sled were imported as XYZ files into the data processing and visualization software SonarWiz 7 (https:/ /chesapeaketech.com/), where they were gridded into a digital elevation model (DEM) using the natural neighbors algorithm and a grid size of $10 \mathrm{~m}$.

Chirp seismic files recorded in the full-waveform JSF format were bandpass-filtered at frequencies of $3,4,10$, and $12 \mathrm{kHz}$ to remove shallow-water artifacts and to enhance vertical resolution of shallow reflections in the seismic data processing program Seismic Unix (Cohen and Stockwell, 2010). Chirp files in the JSF format were converted to SEG-Y format. SEG-Y files were imported into SonarWiz 7 for application of time-varying gain. Heave corrections were applied using the following methodology in SonarWiz to compensate for sea surface roughness encountered during acquisition. First, seafloor picks were automatically tracked in SonarWiz with manual quality assurance and quality control of the picks.
Then, seafloor picks were vertically aligned to the previously discussed, custom-made DEM of gridded single-beam bathymetry in SonarWiz. Gained SEG-Y files were imported into the Kingdom software package (https://ihsmarkit.com/products/ kingdom-seismic-geological-interpretation-software.html) for interpretation of surfaces. Interpretations of sediment units were based on sequence-stratigraphic principles (Mitchum and others, 1977; Christie-Blick and Driscoll, 1995). The "math on two maps" tool in Kingdom Suite software was used to calculate the difference (in two-way travel time) between the seafloor and interpreted surfaces. Two-way travel time was converted to sediment thickness, in meters, using a sound velocity of $1,500 \mathrm{~m} / \mathrm{s}$ in the water column and an internal sound velocity of $1,650 \mathrm{~m} / \mathrm{s}$ in sediment. This sound velocity was used for similar studies at Fire Island in New York by Locker and others (2017). Sediment unit thickness and reflector depth maps were gridded using the surface function within Generic Mapping Tools (https://www.generic-mapping-tools.org/) version 6.0.0 software and exported to Esri's ArcMap geographic information system program for visualization.

Within ArcMap, sediment thickness maps were clipped to boundaries of geomorphic zones. These clipped sediment thickness maps were imported into the Surface Volume tool to calculate the Holocene and shoreface sediment unit volume within each zone (table 1). To estimate the volume of sediment, in cubic meters, at each profile location, transects were drawn along chirp lines that were perpendicular to shore (odd-numbered chirp dip profiles). The ArcMap add-on, Xtools, was used to extract sediment thickness along these transects. Individual transect profiles were plotted, and the Trapezoidal function within MATLAB integrated the area under each profile. This integrated value represents the volume of sediment at each shore-perpendicular seismic profile.

Table 1. Volumes of Holocene and shoreface sediment deposits subdivided by region and total volumes.

$\left[\mathrm{m}^{2}\right.$, square meter; $\mathrm{m}^{3}$, cubic meter; \%, percent; $\mathrm{m}^{3} / \mathrm{m}$, cubic meter per meter; --, no data or not applicable]

\begin{tabular}{|c|c|c|c|c|}
\hline Geomorphic zone & Deposit area $\left(1 \times 10^{6} \mathrm{~m}^{2}\right)$ & Deposit volume $\left(1 \times 10^{6} \mathrm{~m}^{3}\right)$ & $\begin{array}{c}\text { Deposit volume in each } \\
\text { zone }(\%)\end{array}$ & $\begin{array}{l}\text { Volume normalized by } \\
\text { zone width }\left(\mathrm{m}^{3} / \mathrm{m}\right)\end{array}$ \\
\hline \multicolumn{5}{|c|}{ Holocene sediment } \\
\hline I & 10.10 & 47.40 & 56.87 & $10,378.89$ \\
\hline II & 6.83 & 17.66 & 21.19 & $5,867.01$ \\
\hline III & 11.80 & 8.99 & 10.78 & $1,781.49$ \\
\hline IV & 6.89 & 9.29 & 11.15 & $2,707.44$ \\
\hline Total & 35.62 & 83.34 & -- & -- \\
\hline \multicolumn{5}{|c|}{ Shoreface sediment } \\
\hline I & 2.34 & 4.48 & 24.33 & 980.17 \\
\hline II & 2.10 & 4.94 & 26.87 & $1,642.20$ \\
\hline III & 2.89 & 4.49 & 24.39 & 889.60 \\
\hline IV & 3.05 & 4.49 & 24.42 & $1,309.36$ \\
\hline Total & 10.38 & 18.40 & -- & -- \\
\hline
\end{tabular}


The bathymetry of the shelf was mapped from the 2-16-m depths using two Teledyne Reson Seabat T50-P multibeam echosounders in dual-head configuration that used a $200-\mathrm{kHz}$ pulse to acquire swath bathymetry with a 1-millimeter vertical resolution and a 0.6-m pixel resolution (Stalk and others, 2020). The spatial coverage of the multibeam survey is 23.1 square kilometers (fig. $2 A, B$ ). Navigation on the boat was recorded by an Applanix Pos MV Wavemaster II, and motion was recorded by an inertial measurement unit. Bathymetry data were loaded into CARIS, and processing consisted of computing and applying GPS tide corrections, applying sound-velocity corrections, computing total propagated uncertainty, applying filters that excluded points with low RESON quality and high total propagated uncertainty, generating a CUBE model from filtered soundings, removing refraction artifacts, and cleaning manually (Stalk and others, 2020). More details on the acquisition and processing of multibeam data are available in Stalk and others (2020). CARIS extracted the multibeam backscatter, which was exported as a raster for visualization in ArcMap (fig. 2B).

Multibeam swath bathymetry has a narrower footprint in shallow water and some shallow-water areas were inaccessible to the vessel; therefore, $190 \mathrm{~km}$ of single-beam bathymetry in the nearshore zones were acquired by two personal watercrafts that were each equipped with an Odom Echotrac CV100 singlebeam sounder mounted to the back (Stalk and others, 2020). In the cross-shore direction, single-beam tracklines were spaced about $50 \mathrm{~m}$ apart, and 2-3 alongshore transects were collected. All single-beam datasets were merged with navigation data and corrected for sound velocity and tides, as described by Stalk and others (2020). The footprints of the multibeam and single-beam surveys overlap. Single-beam and multibeam bathymetry were merged into a DEM using triangular irregular networks in ArcMap 10 (fig. 2A).

\section{Seismic Stratigraphy}

The most prominent feature in the Rockaway Peninsula chirp seismic profiles is often the regional unconformity, which is a subhorizontal reflection indicated by the green line (figs. $3 A-D$ and 4). In dip profiles 14 and 21, the regional unconformity has a moderate amplitude and a gentle seaward dip (fig. $3 A, B$ ). In strike line 65, the regional unconformity deepens to the west and shoals in the central and eastern peninsula, where it crops out at the seafloor at certain locations (fig. 4). The seaward- and western-dipping structure of the regional unconformity also is apparent in the regional unconformity depth map (fig. 5C).

Below the regional unconformity, the deepest deposits imaged in the seismic profiles are acoustically transparent and are truncated above by channels (shown in yellow in fig. 4). The lower boundary of the acoustically transparent unit could not be detected because of a lack of penetration. Channels that incise into the basal unit are infilled by either acoustically transparent sediment or by deposits that contain flat-lying or dipping reflections (figs. $3 B-D$ and 4). Where present, the upper surfaces of channels are truncated by the regional unconformity that can be traced along the entirety of the survey area and dips towards the west (figs. 4 and 5C).

Any sediment overlying the regional unconformity is within the upper unit; thus, upper unit sediment encompasses "active shoreface" sediment and seafloor features with positive morphology (for example, nearshore bars, ebb-tide deltas, and sorted bedforms). These features with positive morphology also are observed in the multibeam bathymetry and backscatter maps (fig. $2 A, B$ ). Upper unit sediment is thickest in line 14, slightly thinner in line 21 , thin to absent at the seaward parts of line 39, and thick again in line 61 (fig. $3 A-D$ ). This east-west gradient in upper unit thickness also is apparent in strike line 65 (fig. 4). In line 14 and the western part of line 65, internal reflections within the thick upper unit have a seaward and westward dip, which indicates progradation oblique to the margin (figs. $3 A$ and 4 ).

Strike line 65 also captures features in eastern Rockaway Peninsula that have bathymetric expression. At the far eastern end of line 65 is a thick deposit above the regional unconformity with low-amplitude, conformable internal reflections (fig. 4, zone IV). In strike line 65, this feature is cross cut by V-shaped incised valleys (fig. 4), whereas in dip line 61, it appears as a smooth feature (fig. $3 D$ ). This deposit is likely an ebb-tide delta because it is at the mouth of the East Rockaway Inlet (fig. 1). Just west of this feature are undulatory bedforms with less than $2 \mathrm{~m}$ of relief (fig. 4). These features are clearly visible in the seismic data as higher amplitude reflections observed roughly $12-15 \mathrm{~km}$ along the profile (fig. 4). These undulatory bedforms have different acoustic properties than the ebb-tide delta in strike line 65 , because bedform sediment is acoustically transparent compared to the conformable reflections within the ebb-tide delta deposit (fig. 4); furthermore, the bedforms have shorter heights and wavelengths than the ebb-tide delta deposit. These undulatory features also are observed in the multibeam bathymetry and backscatter maps. In the backscatter mosaic, the undulatory bedforms are perpendicular to the shoreline at eastern Rockaway Peninsula and appear as linear, lowreflectivity (dark in the mosaic) areas at the seafloor (fig. $2 B$ ). These dark areas of low acoustic reflectivity are separated by bedform troughs with high reflectivity (light yellow in the mosaic; fig. 2B).

In dip profiles, the landward (north) and steeply dipping part of the seismic profile indicates the extent of the active shoreface. The base of the active shoreface is defined as a weak to high-amplitude reflection. This reflection has weak amplitudes in line 14, moderate amplitudes in line 21, and higher amplitudes in lines 39 and 61 (fig. $3 A-D$ ). The active shoreface was divided into the upper and lower shoreface units based on acoustic character. Where present, internal reflections within the upper shoreface unit (shown in blue) can appear as closely spaced, high amplitude, discontinuous, and chaotic, as observed in lines 14 and 21 (shown in blue in fig. $3 A, B$ ). These characteristics distinguish the upper shoreface unit from the lower shoreface unit (shown in pink), because the latter 


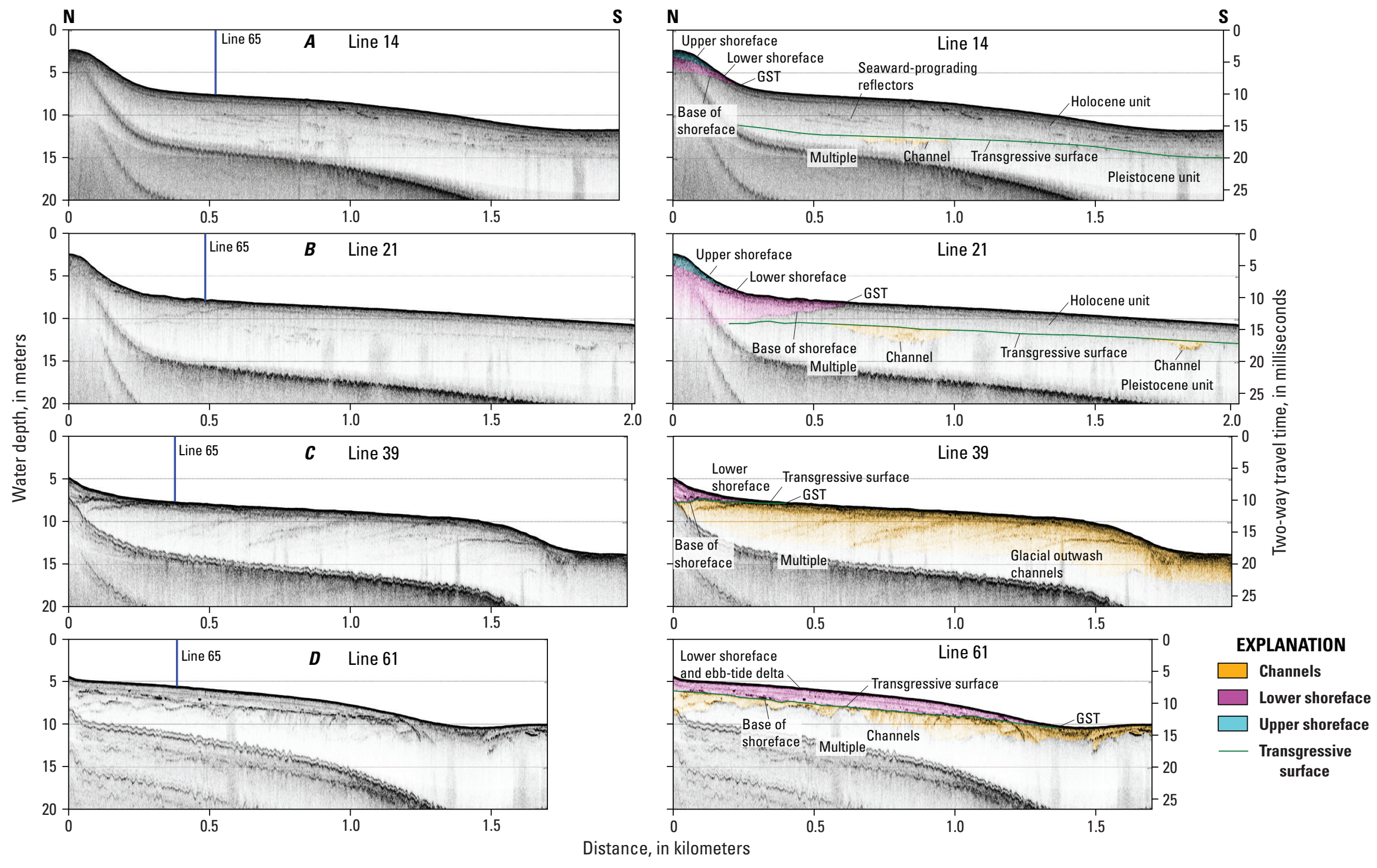

Figure 3. Uninterpreted and interpreted dip profiles showing configurations of shoreface sediment, Holocene sediment above the regional unconformity, and underlying channels. $A$, line 14 is in zone I in west Rockaway Peninsula, New York; $B$, line 21 is in zone II in west-central Rockaway Peninsula; $C$, line 39 is in zone III in east-central Rockaway Peninsula; $D$, line 61 is in zone IV in east Rockaway Peninsula. Line locations are shown in figure 1. The intersections of each dip line with line 65 in figure 4 are indicated by the blue vertical lines. [GST, geologic shoreface toe] 


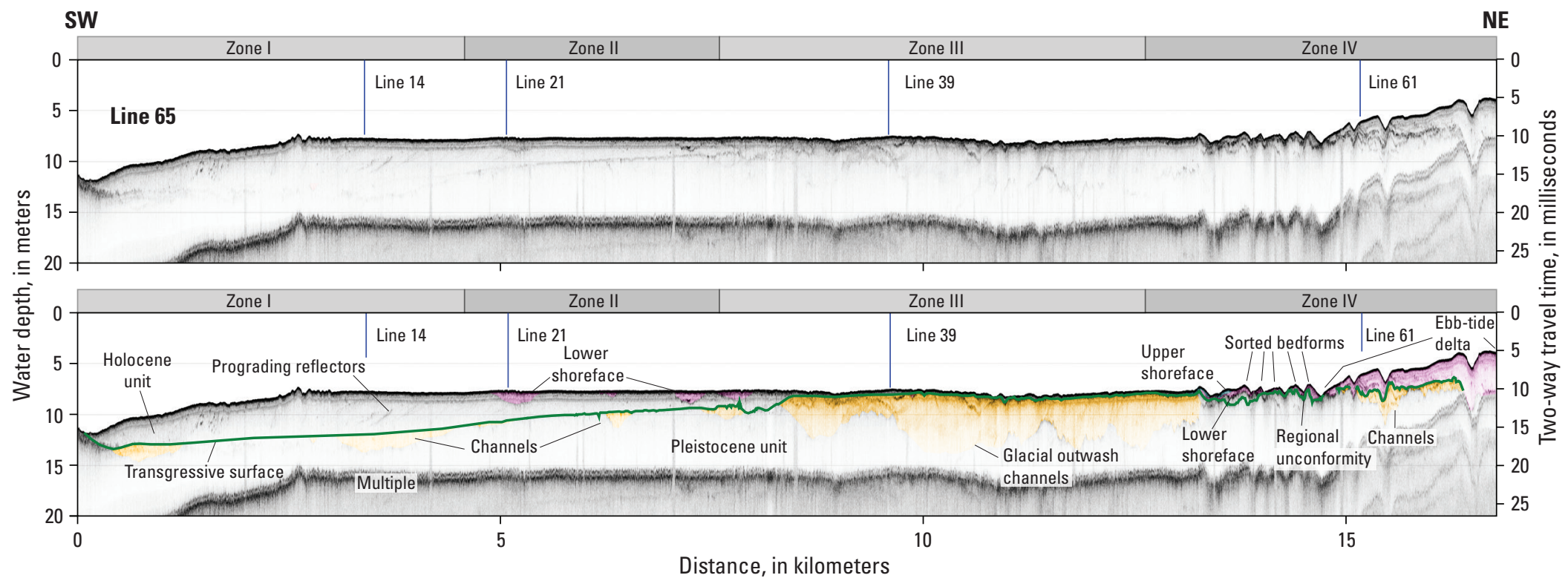

EXPLANATION

$\square$ Channels

$\square$ Lower shoreface

$\square$ Upper shoreface

- Transgressive surface

Figure 4. Uninterpreted and interpreted profile of strike line 65 show the westward dip of the regional unconformity, westward thickening of Holocene sediment, and thickening Holocene sediment in the east because of the ebb-tide delta. Line 65 location is shown in figure 1. Above the profiles, gray rectangles delineate the extent of the geomorphic zones. The intersections of line 65 with dip lines in figure 3 are indicated by the blue vertical lines. 


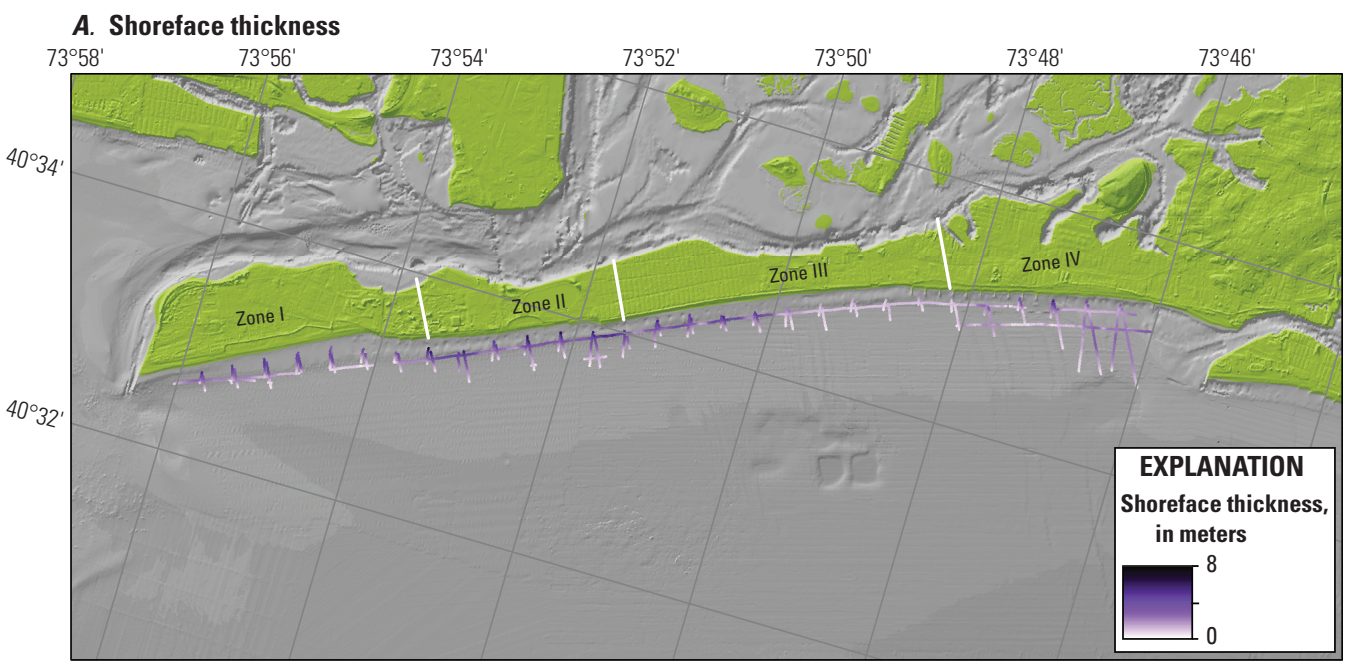

\section{B. Holocene sediment thickness}

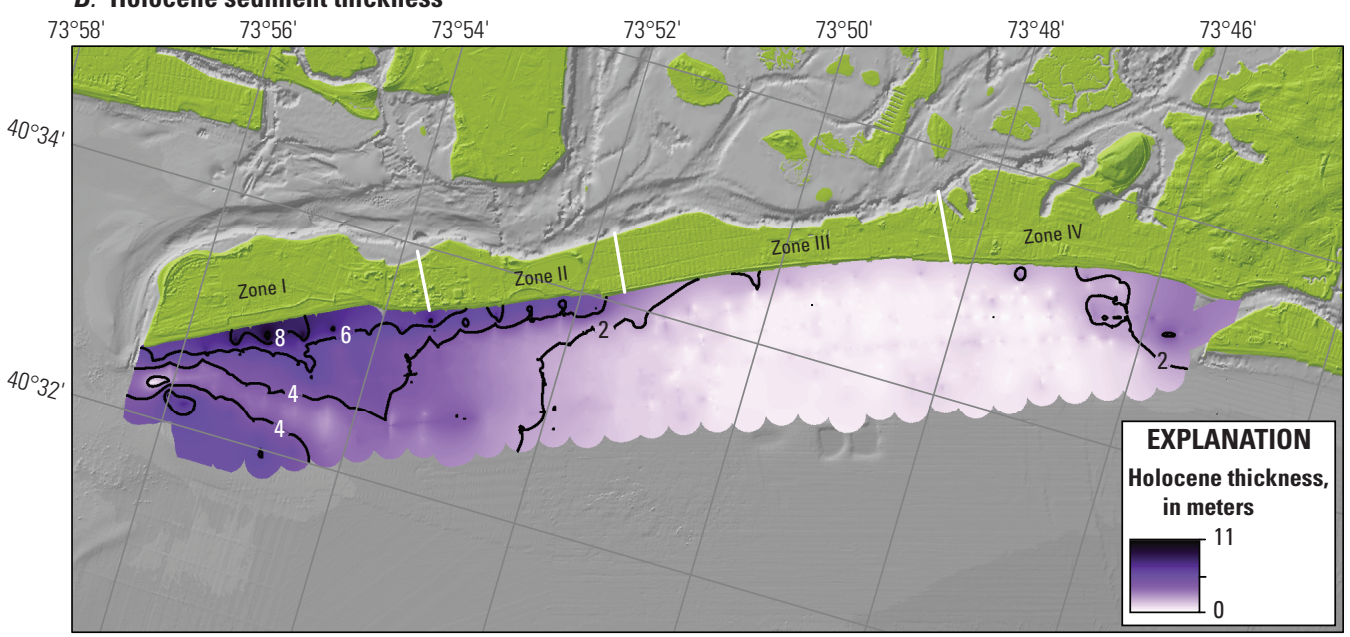

C. Depth of the regional unconformity

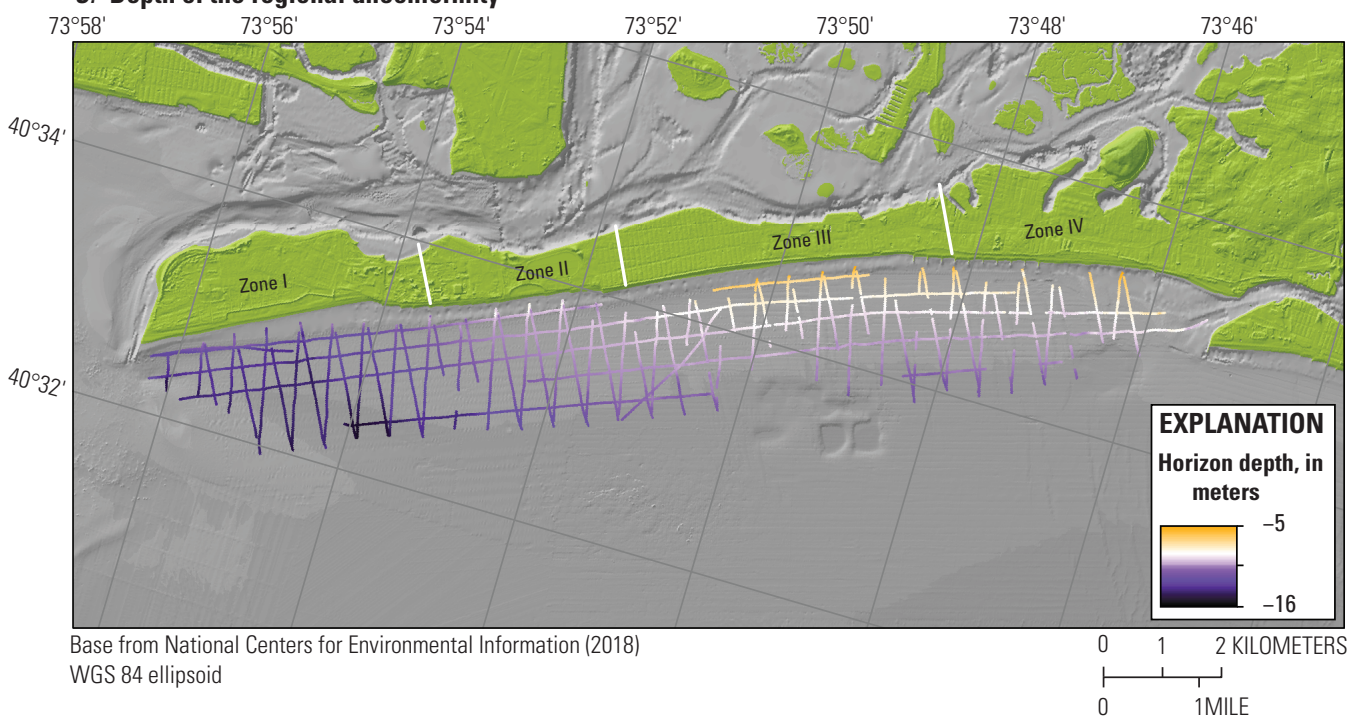

Figure 5. Shoreface and Holocene sediment thickness and depth of the regional unconformity. $A$, shoreface thickness, in meters; $B$, Holocene sediment thickness with contours labeled in meters; $C$, depth of the regional unconformity, in meters below the North American Vertical Datum of 1988. [WGS 84, World Geodetic System of 1984] 
is generally acoustically transparent with a few faint internal reflections, as observed in lines 14 and 21 (fig. $3 A, B$ ). Where these faint and discontinuous internal reflectors are observed in lines 39 and 61, they downlap onto the base of the shoreface reflector (fig. $3 C, D$ ). The base of the lower shoreface in line 14 is vertically separated from the regional unconformity by the western Rockaway Peninsula prograding package (fig. $3 A$ ). In line 21 in west-central Rockaway Peninsula, the base of the shoreface dips towards the north such that it intersects the regional unconformity below the seafloor at depths of about $11 \mathrm{~m}$ (fig. $3 B$ ). The shoreface thickness at line 21 is substantially greater than shoreface thickness at lines 14 and 39 (fig. $3 A-C$ ) because the base of the shoreface is farther seaward and seems to be controlled by underlying geology. In line 39 to the east (fig. 3C), the upper shoreface was not imaged because the vessel could not navigate into shallower water because of the presence of submerged groins. In east-central Rockaway Peninsula, the regional unconformity is at or just below the seafloor surface, and the upper sediment unit is thin (fig. 4). The regional unconformity is shallow at lines 39 and 61; therefore, discontinuous internal reflectors within the shoreface downlap directly onto underlying channels in lines 39 and 61, and the base of the shoreface coincides with the regional unconformity (fig. $3 C, D$ ).

\section{Discussion}

Based on interpretations of similar surfaces observed at Fire Island by Schwab and others (2013), Locker and others (2017), and Liu and Goff (2018), this report interprets the regional unconformity as the transgressive surface, which is the erosional surface formed by the landward displacement of the shoreline across the inner shelf and shoreface during Holocene sea-level rise. This study proposes that the upper unit was deposited in shallow submarine environments during sea-level highstand in the late Holocene following the interpretations of Schwab and others (2013), Locker and others (2017), and Liu and Goff (2018), and this report will refer to upper unit sediment hereafter as "Holocene sediment." Thus, the transgressive surface separates Holocene sediment above from older Pleistocene sediment below (figs. $3 A-D$ and 4).

The transgressive surface, Holocene sediment thickness, and active shoreface thickness demonstrate alongshore variability (fig. $5 A-C$ ), which served as the basis for partitioning the peninsula into four geomorphic zones, with zone I in the west and zone IV in the east (fig. 1). This study proposes that variability in Holocene sediment and active shoreface thickness is driven by the westward dip in the transgressive surface because it provides more accommodation in zones I and II (west and west-central; fig. 5A, $B$ ). The volumes of Holocene and active shoreface sediment were calculated within each geomorphic zone (fig. 6A). Additionally, the volume of sediment was normalized by the alongshore width of the zone (table 1).
In zone I (west), thick Holocene deposits can be attributed to natural and human processes. First, westwardincreasing accommodation allows for thicker sediment deposits to accumulate. The westward-prograding reflections within the deposit above the transgressive surface in zone I likely represent the westward growth and elongation of the barrier spit (Sanderson, 2016; USACE, 2019). Second, the construction of the western Rockaway Peninsula jetty in the 1930s trapped sediments transported along shore from the east, resulting in the progradation of the shoreline and shoreface to the south and a seafloor deposit updrift from the jetty. The seaward progradation of the shoreface decreases with increasing distance from the western Rockaway Peninsula jetty. The result is a southwesterly progradational package at the western end of the island.

This combination of geology and human alterations explains why Holocene sediment volume normalized for zone width is substantially higher in zone I and why zone I Holocene deposits account for 56.87 percent of total Holocene sediment volume (table 1). In zone II (west-central), Holocene sediment thins because of the shoaling regional unconformity (fig. 4). Zone III (east-central) has thin to absent Holocene sediment cover over lines 39 and 65 (figs. $3 C$ and 4), and the only Holocene sediment in zone III is contained within the active shoreface (figs. $3 C$ and 5). As a result, Holocene sediment volume normalized by width is substantially smaller in zone III (table 1). In eastern zone IV, Holocene sediment thickness is variable and can be attributed to sorted bedforms and the ebb-tide delta (figs. 3D and 4).

The shoreface unit is thickest in zone II, and this may be due to preexisting paleochannels that deepen the base of the shoreface; as a result, there is more accommodation for shoreface deposits in this region (fig. $3 B$ ). This also can be observed in strike line 65 , where paleochannels formed over the past hundreds of years in zone II cause the lower shoreface to extend farther seaward than in any other zone (fig. 4). Channels in zone II are above the transgressive surface (fig. $3 B$ ), which indicates that they are younger than channels in zones I, III, and IV. Similar channel features that incise into Holocene sediment units at Fire Island were observed by Locker and others (2017) and Liu and Goff (2018) and were interpreted as channels formed by temporary inlets or barrier breaches. Similarly, this study proposes that the alongshore series of channels in zone II represents channelization that occurred at the western end of the peninsula during its earlier period of rapid, westward growth. These tidal channels are important because they increase the volume of active shoreface deposits such that zone II shorefaces have almost twice the normalized volume of zone III shorefaces (table 1). Additionally, the data in table 1 indicate that the deepening of the shoreface base by channels in zone II may be more effective than the westward-dipping transgressive surface in zone I at increasing shoreface volume.

Volumes of zones III and IV shorefaces are affected by the shoaling transgressive surface in eastern Rockaway Peninsula. Limited accommodation associated with the 
shoaling transgressive surface may contribute to the smallest normalized shoreface unit volume in zone III (table 1). The shoaling of the transgressive surface in the east may be related to the presence of deep and laterally extensive channels (fig. 3C) that resemble glacial outwash channels observed offshore of Fire Island (Schwab and others, 2000). If these outwash deposits are composed of coarser sediment, it is possible that sediment derived from glacial outwash could armor the seabed from erosion, similar to what others have observed offshore of Fire Island (Schwab and others, 2013). This armoring could have hindered wave-based erosion that occurred during the sea-level transgression. As a result, erosionally resistant glacial outwash channels may have exerted large controls in the westward dip of the regional unconformity. Where glacial outwash channels are present in the east, the regional unconformity is shallower; on the contrary, glacial outwash channels are absent in central and western Rockaway Peninsula, where the regional unconformity deepens. The westward dip and eastward shoaling of the transgressive surface play a large role in accommodation on the shoreface and inner shelf and likely contribute to smaller shoreface volumes in zone III (table 1). Though the shoaling transgressive surface likely exerts the largest control on shoreface and Holocene unit volumes in zone III, undulatory bedforms in zones III and IV may affect shoreface and Holocene volume on smaller scales. Undulatory bedforms in zones III and IV are interpreted as sorted bedforms, which are asymmetric bedforms commonly formed on coarse-grained deposits that migrate over periods of years to decades and are similarly observed offshore of Fire Island (Schwab and others, 2014; Goff and others, 2015) and the island of Long Beach (Liu and others, 2018). Sorted bedforms may rework underlying glacial outwash deposits and transfer sediment to the inner shelf and shoreface, as proposed at Fire Island by Schwab and others (2014) and Goff and others (2015). Even though zone IV also has limited accommodation because of the shoaling transgressive surface, normalized shoreface volume in zone III is greater than in zone IV because of localized deposition at the ebb-tide delta (figs. $3 D$ and 4). Thus, normalized Holocene sediment volume seems to be controlled by the depth of the transgressive surface, whereas normalized shoreface unit volume seems to be controlled by recent progradation in zone I, underlying tidal channels in zone II, limited accommodation in zone III, and the ebb-tide delta deposits in zone IV.
The volumes of active shoreface and Holocene sediments were extracted at each shore-perpendicular chirp profile, with subbottom profiles spaced about $500 \mathrm{~m}$ apart (fig. 6A, table 2). Results from this analysis reinforce this study's hypothesis that Holocene sediment is highly variable and dependent on the geologic and morphologic characteristics of each zone. On the other hand, active shoreface volumes do not demonstrate as great a magnitude of variability as Holocene sediment volumes (table 1). In parts of zone III and most of zone IV, the volumes of active shoreface and Holocene sediment converge because of limited accommodation, which indicates that in these zones, available Holocene sediment consists entirely of shoreface sediment (fig. 6B). This convergence in zone IV is due to the ebb-tide delta, which represents Holocene and shoreface units. Divergence of Holocene and shoreface unit volumes in zones III and IV occurs in areas with sorted bedforms, which slightly increase Holocene unit volume.

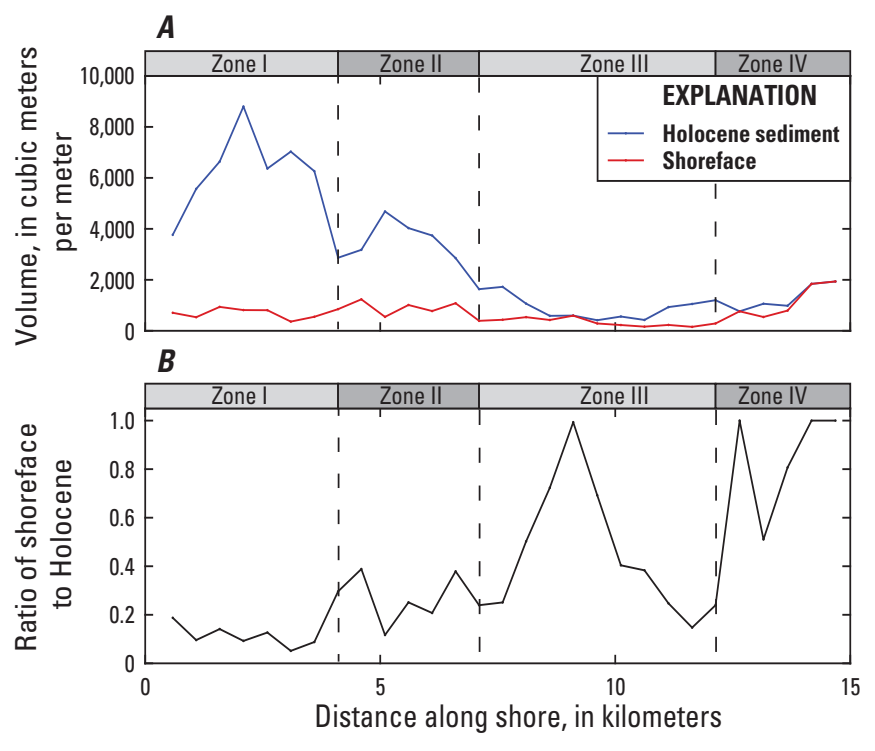

Figure 6. Holocene and shoreface sediment volume and ratio for zones I, II, III, and IV. A, volume, in cubic meters per meter, of Holocene and shoreface sediment is shown for each shore-perpendicular chirp profile. Gray rectangles above the graphs and vertical dashed lines within the graphs delineate the extent of the geomorphic zones. $B$, ratio of shoreface to Holocene sediment. 
Table 2. Volumes of Holocene and shoreface units at each shore-perpendicular chirp line transect.

$\left[\mathrm{m}^{3} / \mathrm{m}\right.$, cubic meter per meter $]$

\begin{tabular}{|c|c|c|}
\hline Chirp line transect & Holocene volume $\left(1 \times 10^{3} \mathrm{~m}^{3} / \mathrm{m}\right)$ & Shoreface volume $\left(1 \times 10^{3} \mathrm{~m}^{3} / \mathrm{m}\right)$ \\
\hline 5 & 4.14 & 0.78 \\
\hline 7 & 6.12 & 0.53 \\
\hline 9 & 7.30 & 1.03 \\
\hline 11 & 9.68 & 0.89 \\
\hline 13 & 7.00 & 0.89 \\
\hline 15 & 7.73 & 0.40 \\
\hline 17 & 6.89 & 0.61 \\
\hline 19 & 3.15 & 0.93 \\
\hline 21 & 3.49 & 1.36 \\
\hline 23 & 5.15 & 0.60 \\
\hline 25 & 4.43 & 1.11 \\
\hline 27 & 4.11 & 0.85 \\
\hline 29 & 3.14 & 1.19 \\
\hline 31 & 1.80 & 0.43 \\
\hline 33 & 1.90 & 0.48 \\
\hline 35 & 1.17 & 0.59 \\
\hline 37 & 0.47 & 0.47 \\
\hline 39 & 0.66 & 0.65 \\
\hline 41 & 0.46 & 0.32 \\
\hline 43 & 0.62 & 0.25 \\
\hline 45 & 0.47 & 0.18 \\
\hline 47 & 1.02 & 0.25 \\
\hline 49 & 1.16 & 0.17 \\
\hline 51 & 1.32 & 0.32 \\
\hline 53 & 0.82 & 0.84 \\
\hline 55 & 1.17 & 0.60 \\
\hline 57 & 0.87 & 0.87 \\
\hline 59 & 2.02 & 2.02 \\
\hline 61 & 2.11 & 2.11 \\
\hline
\end{tabular}

\section{Summary}

This report presents preliminary interpretations of seismic profiles, presents maps of active shoreface and Holocene sediment thickness, and quantifies active shoreface and Holocene sediment volume from the shoreline to about 2 kilometers offshore of the Rockaway Peninsula in New York. This geophysical survey used an acoustic system mounted on a modified, beach-launched towed sled and acquired data in water depths as shallow as 2 meters, which allowed researchers to image more of the upper and lower shoreface than other seismic studies. The results indicate that shoreface and Holocene sediment thickness demonstrates variability that can be linked to geomorphic features and underlying stratigraphy. Holocene sediment is defined as sediment above the transgressive surface and includes the shoreface and seafloor features with positive morphology. Maps indicate that westward-thickening Holocene sediment may be related to accommodation and westward dip of the transgressive surface. The thickness and volume of shoreface units may be related to underlying geology and positive morphological features. The thickest shoreface units in zone II are spatially coincident with deeper geologic bases of the shoreface. Shorefaces of moderate thickness in western and eastern Rockaway Peninsula are spatially coincident with positive morphological features (for example, deposits accumulating updrift from the jetty, ebb-tide deltas, and so on). The thinnest shoreface units are in east-central Rockaway Peninsula because of less accommodation caused by the shoaling transgressive surface and glacial outwash channels. Quantifying the volume of sediment 
in the active shoreface and Holocene packages allows researchers to better understand spatial variability in subaerial barrier response to storms and sea-level rise because sediment within shoreface and inner shelf deposits can be mobilized and transferred to the beach and dunes during storms and rising sea levels. Furthermore, this work supports objectives to evaluate the response of the peninsula to coastal restoration projects, quantify peninsula sediment budgets, and predict the short- and long-term resilience of the Rockaway Peninsula.

\section{Acknowledgments}

Many U.S. Geological Survey employees aided in field operations at sea, on personal watercraft, and on land. We thank Andrew Farmer, Nancy DeWitt, BJ Reynolds, Julie Bernier, Chelsea Stalk, Hunter Wilcox, and Joseph Terrano. Noreen Buster and James Flocks provided helpful insight on seismic processing. We also thank Dave Foster and James Flocks for their insightful reviews.

\section{References Cited}

Brutsché, K.E., Rosati, J., III, Pollock, C.E., and McFall, B.C., 2016, Calculating depth of closure using WIS hindcast data: Vicksburg, Miss., U.S. Army Corps of Engineers, ERDC/CHL CHETN-VI-45, 9 p., accessed June 8, 2020, at https://apps.dtic.mil/sti/citations/AD1006484.

Christie-Blick, N., and Driscoll, N.W., 1995, Sequence stratigraphy: Annual Review of Earth and Planetary Sciences, v. 23 , no. 1, p. 451-478, accessed October 19, 2019, at https://doi.org/10.1146/annurev.ea.23.050195.002315.

Cohen, J.K., and Stockwell, J.W., Jr., 2010, CWP/SU-Seismic Un*x release no. 44-An open source software package for seismic research and processing: Golden, Colo., Center for Wave Phenomena, Colorado School of Mines, accessed November 30, 2020, at https://github.com/ JohnWStockwellJr/SeisUnix.

Cowell, P.J., and Kinsela, M.A., 2018, Shoreface controls on barrier evolution and shoreline change, in Moore, L.J., and Murray, A.B., eds., Barrier dynamics and response to changing climate: Springer International Publishing, Cham, Switzerland, p. 243-275, accessed December 10, 2019, at https://doi.org/10.1007/978-3-319-68086-6_8.

Forde, A.S., Wei, E.A., DeWitt, N.T., and Miselis, J.L., 2021, Archive of chirp subbottom profile data collected in 2019 from Rockaway Peninsula, New York: U.S. Geological Survey data release, accessed July 2021 at https://doi.org/ 10.5066/P9ZO8QKJ.
Goff, J.A., Flood, R.D., Austin, J.A., Jr., Schwab, W.C., Christensen, B., Browne, C.M., Denny, J.F., and Baldwin, W.E., 2015, The impact of Hurricane Sandy on the shoreface and inner shelf of Fire Island, New York-Large bedform migration but limited erosion: Continental Shelf Research, v. 98, p. 13-25, accessed September 17, 2019, at https://doi.org/10.1016/j.csr.2015.03.001.

Hapke, C.J., Lentz, E.E., Gayes, P.T., McCoy, C.A., Hehre, R., Schwab, W.C., and Williams, S.J., 2010, A review of sediment budget imbalances along Fire Island, New York - Can nearshore geologic framework and patterns of shoreline change explain the deficit?: Journal of Coastal Research, v. 263, p. 510-522, accessed December 17, 2019, at https://doi.org/10.2112/08-1140.1.

Liu, S., and Goff, J.A., 2018, Lower shoreface seismic stratigraphy and morphology off Fire Island, New York-Evidence for lobate progradation and linear erosion: Continental Shelf Research, v. 163, p. 23-34, accessed December 30, 2019, at https://doi.org/10.1016/ j.csr.2018.04.013.

Liu, S., Goff, J.A., Flood, R.D., Christensen, B., and Austin, J.A., Jr., 2018, Sorted bedforms off Western Long Island, New York, USA — Asymmetrical morphology and twelve-year migration record: Sedimentology, v. 65, no. 6, p. 2202-2222, accessed December 30, 2019, at https://doi.org/10.1111/sed.12462.

Locker, S.D., Miselis, J.L., Buster, N.A., Hapke, C.J., Wadman, H.M., McNinch, J.E., Forde, A.S., and Stalk, C.A., 2017, Nearshore sediment thickness, Fire Island, New York: U.S. Geological Survey Open-File Report 2017-1024, 21 p., accessed September 20, 2019, at https://doi.org/10.3133/ofr20171024.

Miselis, J.L., and McNinch, J.E., 2006, Calculating shoreline erosion potential using nearshore stratigraphy and sediment volume - Outer Banks, North Carolina: Journal of Geophysical Research, v. 111, no. F2, no. F2, F02019, accessed May 21, 2020, at https://doi.org/10.1029/ 2005JF000389.

Mitchum, R.M., Jr., Vail, P.R., and Sangree, J.B., 1977, Seismic stratigraphy and global changes of sea level-Part 6. Stratigraphic interpretation of seismic reflection patterns in depositional sequences-Section 2. Application of seismic reflection configuration to stratigraphic interpretation, in Payton, C.E., ed., Seismic stratigraphy-Applications to hydrocarbon exploration: Tulsa, Oklahoma, American Association of Petroleum Geologists memoir 26, p. 117-133, accessed October 19, 2019, at https://archives.data pages.com/data/specpubs/seismic1/data/a165/a165/0001/ 0100/0117.htm. 
National Centers for Environmental Information, 2018, NCEI Hurricane Sandy digital elevation models: National Oceanic and Atmospheric Administration, National Centers for Environmental Information digital data, accessed January 20, 2021, at https://www.ngdc.noaa.gov/mgg/ inundation/sandy/sandy_geoc.html.

Rampino, M.R., and Sanders, J.E., 1981, Evolution of the barrier islands of southern Long Island, New York: Sedimentology, v. 28, no. 1, p. 37-47, accessed January 15, 2020, at https://doi.org/ 10.1111/j.1365-3091.1981.tb01661.x.

Sanderson, E.W., 2016, Cartographic evidence for historical geomorphological change and wetland formation in Jamaica Bay, New York: Northeastern Naturalist, v. 23, no. 2, p. 277-304, accessed January 10, 2020, at https://doi.org/ 10.1656/045.023.0208.

Schwab, W.C., Baldwin, W.E., Denny, J.F., Hapke, C.J., Gayes, P.T., List, J.H., and Warner, J.C., 2014, Modification of the Quaternary stratigraphic framework of the innercontinental shelf by Holocene marine transgression-An example offshore of Fire Island, New York: Marine Geology, v. 355, p. 346-360, accessed October 11, 2019, at https://doi.org/10.1016/j.margeo.2014.06.011.

Schwab, W.C., Baldwin, W.E., Hapke, C.J., Lentz, E.E., Gayes, P.T., Denny, J.F., List, J.H., and Warner, J.C., 2013, Geologic evidence for onshore sediment transport from the inner continental shelf-Fire Island, New York: Journal of Coastal Research, v. 29, no. 3, p. 526-544, accessed September 23, 2019, at https://doi.org/10.2112/ JCOASTRES-D-12-00160.1.

Schwab, W.C., Thieler, E.R., Allen, J.R., Foster, D.S., Swift, B.A., and Denny, J.F., 2000, Influence of inner-continental shelf geologic framework on the evolution and behavior of the barrier-island system between Fire Island Inlet and Shinnecock Inlet, Long Island, New York: Journal of Coastal Research, v. 16, no. 2, p. 408-422.

Stalk, C.A., DeWitt, N.T., Wei, E.A., Farmer, A.S., Miselis, J.L., and Fredericks, J.J., 2020, Coastal bathymetry and backscatter data collected in September and October 2019 from Rockaway Peninsula, New York: U.S. Geological Survey data release, accessed February 1, 2021, at https://doi.org/10.5066/P9WNJSFN.
Stive, M.J.F., and de Vriend, H.J., 1995, Modelling shoreface profile evolution: Marine Geology, v. 126, no. 1-4, p. 235-248, accessed July 24,2021 , at https://doi.org/ 10.1016/0025-3227(95)00080-I.

Stone, B.D., and Borns, H.W., Jr., 1986, Pleistocene glacial and interglacial stratigraphy of New England, Long Island, and adjacent Georges Bank and Gulf of Maine: Quaternary Science Reviews, v. 5, p. 39-52, accessed December 19, 2019, at https://doi.org/10.1016/0277-3791(86)90172-1.

Taney, N.E., 1961, Geomorphology of the south shore of Long Island: Beach Erosion Board, U.S. Army Corps of Engineers Technical Memorandum no. 128, 50 p. plus appendixes, accessed December 19, 2019, at https://hdl.handle.net/ $11681 / 3478$.

U.S. Army Corps of Engineers, [USACE], 2016, Atlantic Coast of New York, East Rockaway Inlet to Rockaway Inlet and Jamaica Bay-Draft integrated Hurricane Sandy general reevaluation report and environmental impact statement: U.S. Army Corps of Engineers, New York District, 270 p., accessed October 3, 2019, at https://www.nan.usace .army.mil/Portals/37/docs/civilworks/projects/ny/coast/ Rockaway/RockFeasStudy/1_Rockaway\%20Draft $\% 20$ Integ rated\%20HSGRR\%20and\%20EIS.pdf?ver=2016-08-19094124-930.

U.S. Army Corps of Engineers, [USACE], 2019, Final report-Integrated Hurricane Sandy general reevaluation report and environmental impact statement, Atlantic Coast of New York, East Rockaway Inlet to Rockaway Inlet and Jamaica Bay: U.S. Army Corps of Engineers, New York District, 285 p., accessed September 25, 2019, at https://www.nan.usace.army.mil/Portals/37/docs/ civilworks/projects/ny/coast/Rockaway/Rockaway\%20Final \%20Report/Rock\%20Jam\%20Bay\%20Final\%20Report\%20 HSGRR\%205-9-19.pdf?ver=2019-05-29-124532-717.

Williams, S.J., and Duane, D.B., 1974, Geomorphology and sediments of the Inner New York Bight Continental Shelf: Fort Belvoir, Va., U.S. Army Corps of Engineers, Coastal Engineering Research Center, Technical Memorandum no. 45, 81 p., accessed October 15, 2019, at https://hdl.handle.net/11681/2870. 
For more information about this publication, contact: Director, USGS St. Petersburg Coastal and Marine Science Center 600 4th Street South

St. Petersburg, FL 33701

727-502-8000

For additional information, visit: https://www.usgs.gov/centers/spcmsc

Publishing support provided by the

Reston and Rolla Publishing Service Centers 


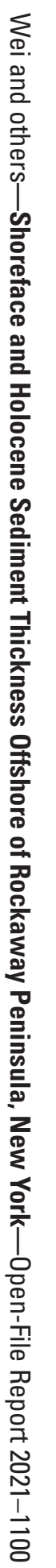

